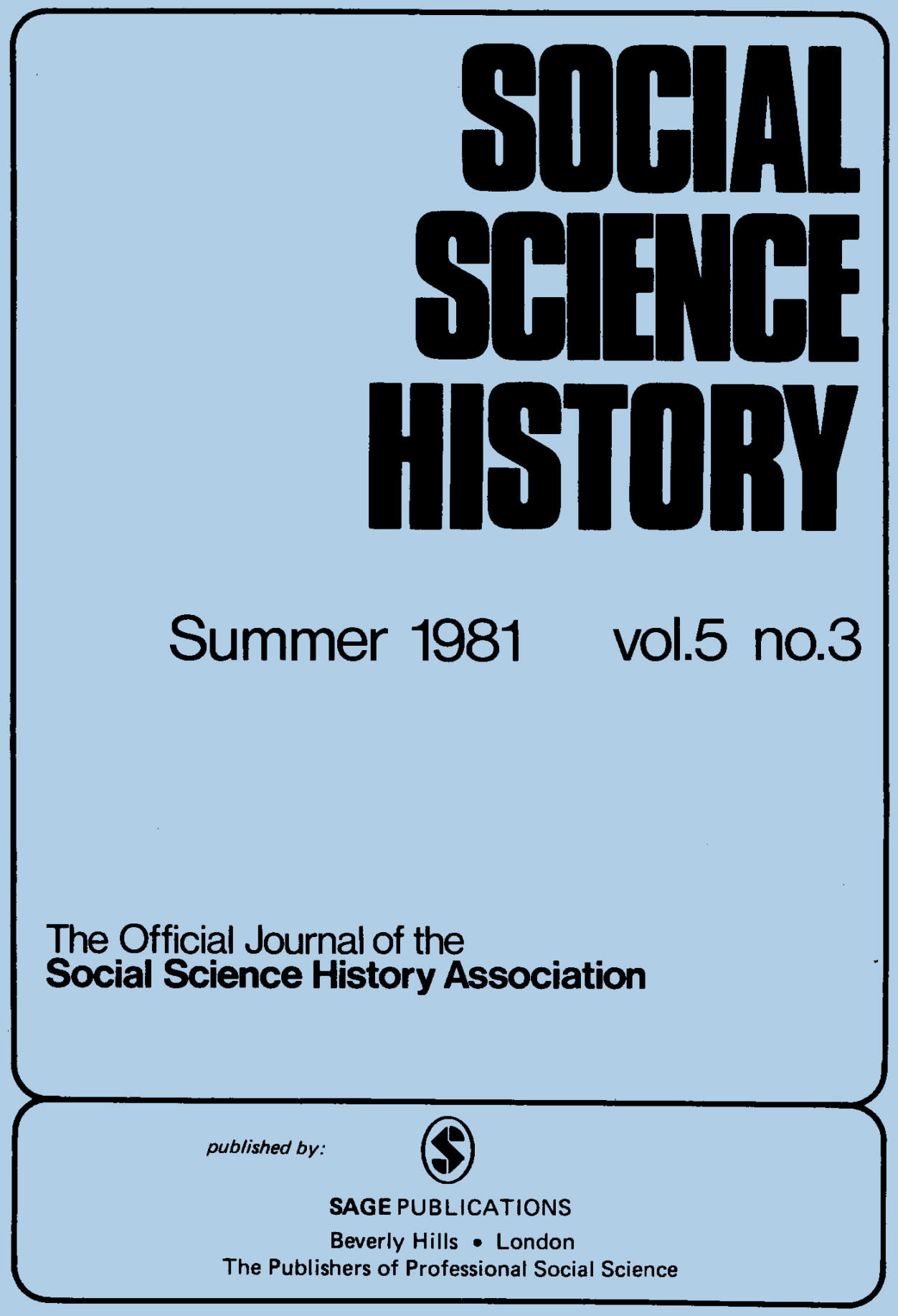




\section{ASSOCIATION OFFICERS}

PRESIDENT

Robert W. Fogel

Harvard University
VICE PRESIDENT

Louise Tilly

University of Michigan
EXECUTIVE DIRECFOR

Jerome M. Clubb

University of Michigan

\section{MANAGING EDITORS}

James Q. Graham, Jr., Bowling Green

State University

Robert P. Swierenga, Kent State University

\section{ASSOCIATE EDITORS}

William O. Aydelotte University of Iowa Lee Benson, University of Pennsylvania
Allan G. Bogue, University of Wisconsin Warren Miller, University of Michigan

\section{EXECUTIVE EDITOR \\ Rachael Rockwell Graham \\ BOARD OF EDITORS}

Thomas B. Alexander, University of Missouri-Columbia

Howard W. Allen, Southern Illinois University

Robert F. Berkhofer, Jr., University of Michigan

Walter Dean Burnham, Massachusetts Institute of Technology

Rondo Cameron, Emory University

Thomas F. Carney, University of Manitoba, Canada

Aage R. Clausen, Ohio State University

Thomas C. Cochran, University of Pennsylvania

Philip D. Curtin, Johns Hopkins University

Hildred Geertz, Princeton University

Clyde Griffen, Vassar College

John Hall, Yale University

Samuel P. Hays, University of Pittsburgh

Barbara Laslett, University of Southern California, Los Angeles
Donald R. Matthews, University of Washington

Birgitta Oden, University of Lund, Sweden

Stein Rokkan, Michaelsen Institute, Norway (deceased)

Gilbert Rozman, Princeton University

Peggy R. Sanday, University of Pennsylvania

G. William Skinner, Stanford University

Daniel Scott Smith, University of Illinois, Chicago Circle

John J. TePaske, Duke University

Charles Tilly, University of Michigan

Paul Uselding, University of Illinois, Urbana-Champaign

Etienne van de Walle, University of Pennsylvania

David Ward, University of Wisconsin

E. A. Wrigley, Cambridge Group for the History of Population and Social Structure 


\section{SOEHAL SEIEIEE HISTORY \\ The Official Journal of the Social Science History Association}

VOLUME 5 Summer 1981

NUMBER 3

\section{CONTENTS}

Social Theory and National Culture: The Case of British and American Absolute Idealism, 1860-1900

David Watson

Land Inequality on the Frontier: The Distribution of Land in East

Tennessee at the Beginning of the Nineteenth Century

Lee Soltow

Fertility and Occupation: Mining Districts in Prewar Japan

Carl Mosk

Interactive, Direct-Entry Approaches to Event Files:

British Contentious Gatherings

R. A. Schweitzer

Steven C. Simmons

Book Reviews

Christopher Lasch, The Culture of Narcissism: American Life in an Age of Diminishing Expectations

John Owen King III

Allan J. Lichtman, Prejudice and the Old Politics:

The Presidential Election of 1928

Richard L. McCormick

David F. Crew, Town in the Ruhr: A Social History of Bochum,

1860-1914

George O. Kent

Charles S. Hyneman, C. Richard Hofstetter, and Patrick F. O'Connor, Voting in Indiana: A Century of Persistence and Change

Albert C.E. Parker

Kristi Anderson, The Creation of a Democratic Majority, 1928-1936

David Burner

Paula Hyman, From Dreyfus to Vichy: The Remaking of French Jewry,

1906-1939

Robert L. Hoffman

Fritz K. Ringer, Education and Society in Modern Europe

Anthony LaVopa 
SOCIAL SCIENCE HISTORY is the journal of the Social Science History Association, and exists to publish material directed to improving the quality of historical explanation in teaching and research of relevant theories and methods from the social science disciplines. It is aimed at social scientists interested in longitudinal analysis and historians seeking a more rigorous and consciously theor etical orientation. The editors encourage and provide a for um for research that attempts generalizations of some breadth verified by systematic examination of the relevant evidence and supported by quantitative analysis when appropriate. Research efforts involving comparisons across time between individuals and groups within a single population and between different and properly comparable populations across space and over time will be particularly welcome. The editors welcome contributions to the development of theory and techniques which, although firmly centered in particular social science disciplines, can provide a genuine interdisciplinary focus in approaching the historical dimension. SOCIAL SCIENCE HISTORY will also inform its readers about new developments in social science data archives, research funding agencies, training programs and summer institutes, and significant new publications in history and the social science disciplines.

MANUSCRIPTS should be submitted in triplicate to James Q. Graham, Jr., Department of History, Bowling Green State University, Bowling Green, $\mathrm{OH} 43403$. They must be typed with all written material double-spaced (including quotations, notes, and the list of references) using only one side of the paper. The typewritten lines should not exceed $51 / 2$ inches in length. See SSH, volume 3, nos. 3-4 and following for style and reference form. Brief parenthetical citations are included in the text, all complete references are listed alphabetically at the end of the article, and notes are used only for discursive comments which appear immediately before the list of references. Manuscripts over 30 pages (including tables, notes, and references) will not be published. A "Guide for Authors" may be obtained from the Editors. The Social Science History Association does not accept responsibility for statements of fact or opinion made by the contributors.

BOOK REVIEWS: All inquiries from publishers, suggestions for books to be reviewed, and questions from prospective book reviewers should be sent to Alan M. Kraut at the Department of History, American University. Nebraska and Massachusetts Avenues, NW, Washington, D.C. 20016.

SOCIAL SCIENCE HISTORY is published quarterly-in February, May, August, and November. Copyright (C) 1981 by the Social Science History Association. All rights reserved. No portions of the contents may be reproduced in any form without written permission from the publisher (address below), editor, and author(s).

Subscriptions: Address all subscription correspondence to the publisher, Sage Publications, Inc., 275 South Beverly Drive, Beverly Hills, CA 90212. Regular institutional rate \$42.00. Individuals may subscribe at a one-year rate of $\$ 20.00$. Add $\$ 2.00$ for subscriptions outside the United States. Orders from the U.K., Europe, the Middle East, and Africa should be sent to the London address (below). Orders from India should be sent to the New Delhi address (below). Noninstitutional orders must be paid by personal check.

Second class postage paid at Beverly Hills, California. ISSN 0145-5532

Back Issues: Information about availability and prices of back issues may be obtained from the publisher's order department (address above). Write to the London office for sterling prices

Inquiries: Membership applications and reprint correspondence should be addressed to Jerome M. Clubb, Center for Political Studies, University of Michigan, Ann Arbor, Mi 48106. Inquiries and subscriptions from the U.K., Europe, the Middle East, and Africa should be sent to SAGE PUBLICATIONS Ltd, 28 Banner Street, London EC1Y 8QE, England. From India, write to SAGE INDIA, P.O. Box 3605, New Delhi 110024 India. Other orders should be sent to the Beverly Hills office.

Advertising: Current rates and specifications may be obtained by writing to the Advertising Manager at the Beverly Hills office (address above).

Claims: Claims for undelivered copies must be made no later than three months following month of publication. The publisher will supply missing copies when losses have been sustained in transit and when the reserve stock will permit.

Change of Address: Six weeks' advance notice must be given when notifying of change of address. Please send old address label along with the new address to ensure proper identification. Please specify name of journal. POSTMASTER: Send change of address to: Journal name, c/o 275 South Beverly Drive, Beverly Hills, CA 90212. 